\title{
Comparison of surface and column measurements of aerosol scattering properties over the western North Atlantic Ocean at Bermuda
}

\author{
R. P. Aryal ${ }^{1,{ }^{*}}$, K. J. Voss ${ }^{1}$, P. A. Terman ${ }^{1, * *}$, W. C. Keene ${ }^{2}$, J. L. Moody ${ }^{2}$, E. J. Welton ${ }^{3}$, and B. N. Holben ${ }^{4}$ \\ ${ }^{1}$ Department of Physics, University of Miami, FL 33146, USA \\ ${ }^{2}$ Department of Environmental Sciences, University of Virginia, Charlottesville, VA 22903, USA \\ ${ }^{3}$ Code 613.1, NASA GSFC, Greenbelt, MD 20771, USA \\ ${ }^{4}$ Code 614.4, NASA GSFC, Greenbelt, MD 20771, USA \\ * now at: Department of Physics, Eckerd College, St Petersburg, FL 33711, USA \\ *** now at: Department of Physics and Astronomy, Texas A\&M University, College Station, TX 77843, USA
}

Correspondence to: K. J. Voss (voss@ physics.miami.edu)

Received: 23 August 2013 - Published in Atmos. Chem. Phys. Discuss.: 21 January 2014

Revised: 4 June 2014 - Accepted: 17 June 2014 - Published: 30 July 2014

\begin{abstract}
Light scattering by size-resolved aerosols in nearsurface air at Tudor Hill, Bermuda, was measured between January and June 2009. Vertical distributions of aerosol backscattering and column-averaged aerosol optical properties were characterized in parallel with a micro-pulse lidar (MPL) and an automated sun-sky radiometer. Comparisons were made between extensive aerosol parameters in the column, such as the lidar-retrieved extinction at $400 \mathrm{~m}$ and the aerosol optical depth (AOD), and scattering was measured with a surface nephelometer. Comparisons were also made for intensive parameters such as the Ångström exponent and calculations using AERONET(Aerosol Robotic Network)derived aerosol physical parameters (size distribution, index of refraction) and Mie theory, and the ratio of submicron scattering to total scattering for size-segregated nephelometer measurements. In these comparisons the $r^{2}$ was generally around 0.50. Data were also evaluated based on back trajectories. The correlation between surface scattering and lidar extinction was highest for flows when the surface scattering was dominated by smaller particles and the flow had a longer footprint over land then over the ocean. The correlation of AOD with surface scatter was similar for all flow regimes. There was also no clear dependence of the atmospheric lapse rate, as determined from a nearby radiosonde station, on flow regime. The Ångström exponent for most flow regimes was $0.9-1.0$, but for the case of air originating from North America, but with significant time over the
\end{abstract}

ocean, the Ångström exponent was $0.57 \pm 0.18$. The submicron fraction of aerosol near the surface $\left(R_{\text {sub-surf }}\right)$ was significantly greater for the flows from land $(0.66 \pm 0.11)$ than for the flows which spent more time over the ocean $(0.40 \pm 0.05)$. When comparing $R_{\text {sub-surf }}$ and the columnintegrated submicron scattering fraction, $R_{\text {sub-col }}$, the correlation was similar, $r^{2}=0.50$, but $R_{\text {sub-surf }}$ was generally less than $R_{\text {sub-col }}$, indicating more large particles contributing to light scattering at the surface, contrary to conditions over continents and for polluted continental transport over the ocean. In general, though, the marginal correlations indicate that the column optical properties are weakly correlated with the surface optical measurements. Thus, if it is desired to associate aerosol chemical/physical properties with their optical properties, it is best to use optical and chemi$\mathrm{cal} / \mathrm{physical}$ measurements with both collected at the surface or both collected in the column.

\section{Introduction}

Aerosols play an important role in the radiation budget of the Earth-Atmosphere system by scattering and absorbing solar and terrestrial radiation (direct effect) and by modulating microphysical properties and associated albedos of clouds (indirect effect) (Kaufman et al., 2006). Aerosols originate from multiple sources including the surface ocean, fossil-fuel and 
biomass combustion, deflation of surface soils, and nucleation pathways, each of which impart distinct chemical and physical characteristics. Aerosols are also transported thousands of kilometers by prevailing winds, and their physiochemical properties evolve over time via multiphase chemical transformations, cloud processing, and deposition. Consequently, their radiative properties vary significantly over time and space (Forster et al., 2007). Large uncertainties in the radiative influences of atmospheric aerosols represent a major constraint in our ability to predict Earth's climate (IPCC, 2007).

Detailed measurements of near-surface aerosol characteristics provide important constraints in developing reliable retrieval algorithms for remotely sensed parameters. More generally, synchronized measurements from ground- and satellite-based platforms facilitate more reliable spatial and temporal extrapolation of the chemical, physical, and optical properties of aerosols and their associated climatic implications (Russell et al., 2000; Bates et al., 2006). For logistical reasons, long-term measurement campaigns of aerosol physiochemical properties are typically limited to surface sites. These measurements are often assumed to be representative of the overlying aerosol column, or at least of the aerosol boundary layer. Several experiments have been conducted to characterize the connection between surface and column aerosol properties (Bergin et al., 2000; Andrews et al., 2004; Slater and Dibb, 2004; Sheridan et al., 2012; Quinn et al., 2004). Most of these experiments were at continental locations including Oklahoma (Bergin et al., 2000; Andrews et al., 2004), rural New England (Slater and Dibb, 2004), central Illinois (Sheridan et al., 2012), and Big Bend, Texas (Hand et al., 2004).

These studies have examined both extensive parameters, which depend on the quantity of aerosol, such as the extinction coefficient and aerosol optical depth (AOD), and intensive parameters, which depend on the characteristics of the aerosols, such as the scattering Ångström exponent defined below. Andrews et al. (2004) found, in Oklahoma, that the surface measurements tended to be representative of the column measurements when averaged over a long time frame, but even the intensive properties did not correlate well with the day-to-day variation of the aerosol properties. Sheridan et al. (2012), also using an instrumented light aircraft, found that the intensive properties of the aerosols were generally more consistent through the boundary layer than the extensive properties. However they did find at their site that the fraction of small particles was larger near the surface relative to higher altitudes. Bergin et al. (2000) concluded that attempts to predict column AOD from surface measurements, both with and without associated lidar measurements, underestimated the measured column AOD by between 30 and $70 \%$. Slater and Dibb (2004) found, in rural New England, that there was only a moderate correlation of surface and column aerosol properties. One study, conducted over the ocean (Quinn et al., 2004) reported that the average surface and col- umn Ångström exponents (an intensive property) were similar for marine atmospheres but diverged in the presence of dust and/or pollution aerosols; in these cases the extinction Ångström exponent at the surface was relatively higher, indicating a larger impact for small particles in the near-surface atmosphere.

These studies were generally the result of either large short-term intensive field efforts (ACE Asia, Quinn et al., 2004) or studies involving numerous flights by small light aircraft (Sheridan et al., 2012). In this study, we investigated relationships between aerosol optical properties measured simultaneously at the surface and in the column at Bermuda, a moderately polluted marine location, based on a relatively long-term (6-month) data record and without in situ column measurements. The goal of this paper is to describe how well surface level aerosol optical properties represent the column aerosol properties in this marine environment and to apply a method to test this correlation without in situ column measurements.

\section{Methods}

\subsection{Site description and sampling strategy}

Bermuda $\left(32.24^{\circ} \mathrm{N}, 64.87^{\circ} \mathrm{W}\right)$ is influenced by the longrange transport of chemically and optically distinct air masses originating from different source regions, the relative importance of which varies seasonally (Galloway et al., 1989; Moody et al., 1995, 2013; Anderson et al., 1996). Westerly flow, which is most frequent during winter and spring, transports emission products from North America, over the western North Atlantic, to the island. Southerly and southeasterly flow, which is most prevalent during summer, transports Saharan dust intermixed with emission products from Europe and Africa to the island. Similar flow patterns also deliver aged marine air from the central Atlantic that contains relatively minor concentrations of constituents originating from continental sources. The chemical and physical characteristics of all air mass types evolve during transport via chemical processing including interactions with marinederived aerosols and gases, entrainment from the free troposphere, and wet and dry deposition.

The chemical and physical properties of near-surface aerosols at Bermuda have been characterized by several programs (e.g., Galloway et al., 1993; Moody et al., 1995, 2014; Keene and Savoie, 1998; Keene et al., 2002; Savoie et al., 2002; Turekian et al., 2003) and the site is widely viewed within the research community as a critical baseline site for long-term climate-relevant observations (e.g., see planning documents for the international and US Surface Ocean Lower Atmosphere Study (SOLAS) http://www.uea.ac.uk/env/solas/ and http://www.aoml.noaa. gov/ocd/solas/ and documentation for the World Climate 
Research Program (WCRP) Baseline Surface Radiation Network (BSRN) http://bsrn.ethz.ch/).

Between January and June 2009, optical properties of aerosols in near-surface air and in the overlying column were measured continuously at the Tudor Hill Atmospheric Observatory on the western coast of Bermuda. Inlets for air sampled near the surface were located at the top of a $23 \mathrm{~m}$ scaffolding tower ( $43 \mathrm{~m}$ above mean sea level) that had been installed and operated previously by the Aerosol Oceanic Chemistry Experiment (AEROCE) program (Galloway et al., 1993; Savoie et al., 2002). Each measurement technique is described below.

\subsection{Measured scattering characteristics of near-surface aerosols}

Light scattering coefficients of near-surface aerosols at a wavelength of $530 \mathrm{~nm}$ were measured continuously with a Radiance Research M903 integrating nephelometer (Li et al., 1996; Li-Jones et al., 1998; Moody et al., 2014). Ambient aerosols were drawn through an omnidirectional inlet (Liu et al., 1983) at the top of the tower and transmitted under laminar flow through a $20 \mathrm{~cm}$ diameter polyvinyl chloride plenum to the instrument at the base of the tower. Measured transmission efficiencies through the plenum were indistinguishable from $100 \%$ (D. L. Savoie, personal communication, 1996). The inlet for the nephelometer was designed with a $50 \%$ aerodynamic cut at $10 \mu \mathrm{m}$ dry diameter. For marine aerosol, this corresponds to an approximately $20 \mu \mathrm{m}$ diameter at $80 \%$ RH (relative humidity). Air from the center of the plenum was drawn through (1) an inlet heated to a temperature of $28 \pm 5^{\circ} \mathrm{C}$ to dehydrate aerosols prior to analysis, (2) an inertial impactor to differentiate size fractions, and then (3) the nephelometer. The switched impactor was configured with aerodynamic size cuts of 10 and $1.0 \mu \mathrm{m}$ diameter to alternately characterize scattering by bulk and sub- $\mu \mathrm{m}$-diameter size fractions. Scattering by super- $\mu \mathrm{m}$-size fractions was calculated by difference (bulk minus sub- $\mu \mathrm{m}$ ). Temperature and $\mathrm{RH}$ in the sampling chamber were monitored and recorded. Data evaluated in this paper correspond to internal RHs of less than $40 \%$. The nephelometer was routinely calibrated with clean $\mathrm{CO}_{2}$ (Anderson and Ogren, 1998). During each hour, clean particle-free air was introduced into the chamber to obtain a zero value for $20 \mathrm{~min}$, scattering by bulk aerosol was measured for $20 \mathrm{~min}$, and scattering by sub- $\mu \mathrm{m}$ aerosol was measured for $20 \mathrm{~min}$.

The scattering coefficient (in $\mathrm{Mm}^{-1}$ ) at $530 \mathrm{~nm}$ for each size fraction (sub- $\mu \mathrm{m}$ and bulk) in near surface air ( $\left.b_{\text {size-surf }}\right)$ was calculated via

$b_{\text {size-surf }}=\left[\frac{b_{\text {size-surf }}-b_{\text {zero }}}{b_{\text {cal }}-b_{\text {zero }}}\right] \cdot 20 \mathrm{Mm}^{-1}$,

where $b_{\text {size-surf }}$ is size-segregated scattering measured in ambient samples, $b_{\text {cal }}$ is scattering by clean $\mathrm{CO}_{2}, b_{\text {zero }}$ is scattering by particle-free air. The scattering coefficient due to clean $\mathrm{CO}_{2}$ is $20 \mathrm{Mm}^{-1}$ based on the average temperature of $28 \pm 5^{\circ} \mathrm{C}$ and pressure of $995 \pm 11 \mathrm{mb}$ (Anderson and Ogren, 1998). The scattering coefficients were then filtered to remove values outside the operating range specified by the manufacturer ( 1 to $1000 \mathrm{Mm}^{-1}$ ). Values exceeding the upper limit typically reflected artifacts associated with overheating of the instrument. The continuous data set was then filtered to extract the subset of scattering data that corresponded to periods of no precipitation during which on-shore winds came from the open-ocean sector at velocities greater than $1 \mathrm{~m} \mathrm{~s}^{-1}$, thereby minimizing local influences. The reported values of the scattering coefficient were adjusted to account for truncation error, which exists due to the internal geometry of the instrument that prevents measurement in the near-forward and near-backward scattering region. Anderson and Ogren (1998) showed that the nephelometer is sensitive to scattering of light in the angular range of $\sim 7-170^{\circ}$. The truncation error is present both during calibration of the nephelometer and during measurement of aerosol light scattering. In this text we have used an average correction factor for scattering by sub- $\mu \mathrm{m}$ and bulk aerosols, $1.08 \pm 0.004$ and $1.18 \pm 0.04$, respectively, which were determined based on calculations from Mie theory. The input parameters, aerosol volume size distribution, and index of refraction were obtained from AERONET (Aerosol Robotic Network) inversions (Holben et al. 1988) for the Bermuda site (e.g., see Sect. 2.3.1). The relative contribution of particle-free air to this correction factor was calculated using a Rayleigh scattering phase function (Ensor et al., 1970).

The spectral aerosol absorption was also measured in parallel at the site using a filter reflectance technique (see Moody et al., 2014) but these data are not evaluated in this paper because there were no corresponding column measurements with which to compare and because the time resolution of the absorption measurement (daily averages) did not match well with the other measurements used in the paper.

\subsection{Measurements and calculated characteristics of the atmospheric column}

\subsubsection{Sun and sky radiometer}

An automated Cimel sun and sky radiometer was deployed at the top of the tower in December 2007 as a part of AERONET. Numerous publications describe the instrumentation, data acquisition, retrieval algorithm, calibration procedures and cloud-screening procedures as well as the uncertainty of the final products (Holben et al., 1998; Smirnov et al., 2000). Direct solar irradiance is measured at eight spectral channels - 340, 380, 440, 500, 675, 870, and $1020 \mathrm{~nm}$ - and used to compute the AOD $(\tau)$. The uncertainty in retrieval of $\tau$ under cloud-free conditions is less than \pm 0.01 for $\lambda$ greater than $440 \mathrm{~nm}$ and less than \pm 0.02 for shorter wavelengths (Holben et al., 1998; Eck et al., 1999). 
In addition, sky radiance was measured at $440,670,870$, and $1020 \mathrm{~nm}$ through a large range of scattering angles from the sun several times in the day. The sky radiance and direct solar irradiance were used, assuming a constant aerosol profile, to retrieve the column-averaged size distribution and the spectral refractive index. AERONET provides inversion products for three data quality levels: level 1.0 (unscreened), level 1.5 (automatically cloud screened) following the methodology as described by Smirnov et al. (2000), and level 2 (cloud screened and quality assured). The analysis reported here is based on level 2 products.

Dubovik et al. (2000) investigated the accuracy of the AERONET inversion products and found that while the size distribution of the aerosols could be resolved reliably at all aerosol optical depths, the inversion for the complex index of refraction was sensitive to this factor. The real portion of the index of refraction had an uncertainty of 0.05 for $\tau_{440}$ less than 0.2 , and the imaginary part had an uncertainty of 80 $100 \%$ for these low values. The complex index of refraction was reliably retrieved for $\tau_{440}$ greater than 0.4 . In the data set used in this paper we had no cases with $\tau_{440}$ greater than 0.4 , and only one case with $\tau_{440}$ greater than 0.2 . We had to use the complex index of refraction resulting from the inversion in our Mie calculations, described below, and accept that the uncertainty in this value could be large. Because the imaginary part of the index of refraction determines the absorption of the aerosol and was highly uncertain, we did not compare our surface absorption measurement with the derived column absorption properties.

\subsubsection{Micro-pulse lidar}

A micro-pulse lidar (MPL; Spinhirne et al., 1995) - lidar stands for light detection and ranging - was installed at the base of the tower in March 2008 and operated continuously during the measurement period as part of NASA's MPL Network (MPLNET; Welton et al., 2001). The MPL system employs an optical transceiver that acts as both transmitter and receiver (telescope) and consists of a diodepumped ND: YLF (neodymium-doped yttrium lithium fluoride) laser at $527 \mathrm{~nm}$, a single photon-counting module (SPCM) avalanche photo diode (APD) detector, a signal processing unit, and a data processor. MPLNET level 1 signal profiles and associated uncertainties (Campbell et al., 2002; Welton et al., 2002) are generated continuously, at $75 \mathrm{~m}$ vertical and $1 \mathrm{~min}$ time resolutions. Profiles of aerosol extinction and backscatter are retrieved from 20 min cloud cleared Level 1 signal averages using the collocated AOD data as a constraint (Welton et al., 2000). This process also retrieves a column average extinction-to-backscatter ratio (or lidar ratio). Due to instrumental constraints, the lowest recoverable altitude is $\sim 400 \mathrm{~m}$. MPLNET data quality levels are identical to AERONET, with both level 1.5 and 2 aerosol products available. In the present study we used MPLNET level 2 data, which were available at times centered on the AERONET
AOD data times, so the AERONET AOD data could be used in the lidar inversions (Welton et al., 2000).

\subsubsection{Mie calculations}

To determine additional intensive column parameters to compare with our surface-size-segregated scattering measurements, we used Mie theory and column-derived physical aerosol properties. Using the column-averaged aerosol size distribution and index of refraction from the AERONET inversions, we calculated the column-averaged aerosol scattering for sub- $\mu \mathrm{m}$ (diameter $(d)<1 \mu \mathrm{m}$ ) and bulk aerosol $(d<10 \mu \mathrm{m})$ based on Mie scattering theory. This assumes that the aerosol population is comprised of polydisperse, homogeneous spherical particles (complex refractive index constant for all sizes). With Mie theory, we calculated the scattering efficiency, $Q_{\text {scatt }}(x, m)$, which is defined as the ratio of the scattering cross section of a spherical particle to its projection on the plane perpendicular to the beam propagation direction (Bohren and Huffman, 1983), where $x$ is the size parameter $(=\pi d / \lambda), d$ is the particle diameter, $\lambda$ is wavelength, and $m$ is the complex refractive index. With $Q_{\text {scatt }}(x, m)$, we calculated the column scattering portion of the AOD, $\tau_{\mathrm{s}}$, using an integral over the columnar size distribution $n_{\mathrm{c}}(\mathrm{d})$, i.e., the numbers of particles per unit lateral area per unit radius in a vertical column through the atmosphere (King et al., 1978)

$\tau_{\mathrm{s}}=\int_{d_{\min }}^{d_{\max }} \frac{\pi d^{2}}{4} Q_{\text {scat }}(x, m) n_{c}(d) d d$,

where $d$ is the diameter of aerosol particles in the size range between $d_{\min }$ and $d_{\max }$.

The columnar size distribution can be rewritten in terms of the volume size distribution as:

$n_{\mathrm{c}}(d)=\frac{6}{\pi d^{4}} \cdot \frac{d V(d)}{\mathrm{d} \ln d}$.

The temporal complex refractive indices at $530 \mathrm{~nm}$ were obtained by interpolating corresponding temporal spectral AERONET inversion data between the spectral refractive index data at $438 \mathrm{~nm}$ and $675 \mathrm{~nm}$, assuming that the aerosol refractive index is a weak function of the wavelength in this wavelength range. The AERONET inversion gave the volume size distribution $(d V(d) / d \ln d)$ at 22 logarithmically equidistant points in the size range $0.1 \mu \mathrm{m} \leq d \leq 30 \mu \mathrm{m}$ (Dubovik and King, 2000). These ambient volume size distributions were interpolated at $0.004 \mu \mathrm{m}$ diameter steps in the two different size ranges of $d<1 \mu \mathrm{m}$ and $<10 \mu \mathrm{m}$ for quantitative comparison with the near-surface sub- $\mu \mathrm{m}$ and bulk dehydrated aerosol data. 


\subsubsection{Radiosonde measurements}

Radiosonde measurements are performed twice daily at the L. F. Wade International Airport by the Bermuda Weather Service. Data for our measurement period was downloaded from the NOAA Integrated Global Radiosonde Archive (IGRA). The radiosonde temperature data below $1 \mathrm{~km}$ (typically only 2-3 data points) were used to calculate a lapse rate (Calvert, 1990) for the lower atmosphere, which can be used as an indication of the stability of the atmosphere. The average atmospheric lapse rate is $-6.5^{\circ} \mathrm{C} \mathrm{km}^{-1}$; values less than this indicate a stable atmosphere, less likely to be well mixed, while values above indicate an unstable atmosphere, and are more likely to be well mixed (Calvert, 1990). We also used the dew point temperature depression to calculate the relative humidity (Lawrence, 2005) and interpolate this parameter to the altitude of the lowest MPL extinction measurement $(400 \mathrm{~m})$.

\subsubsection{Flow regime analysis}

To evaluate influences of source region and transport, the data set was classified by transport pattern using the particle dispersion model, FLEXPART (Stohl et al., 1998, 2005), run in back trajectory mode (Stohl et al., 2003; Seibert and Frank, 2004). The FLEXPART trajectories were classified into five groups depending on fractional footprint residence times. These groups were northeastern United States (NEUS), southeastern United States and the Gulf of Mexico (East-SEUS), northern Africa and the eastern tropical Atlantic (Africa), Ocean when the transport resulted in long residence times over the open ocean, and North, a combination of North Atlantic and northeastern United States. More details on this breakdown are provided in Moody et al. (2014).

\subsubsection{Linear regression method}

All regressions were calculated using the trust-region Levenberg-Marquardt least orthogonal distance method as implemented in IGOR (Wavemetrics) using the ODRPACK95 (orthogonal distance regression package) code (Boggs et al., 1998). These regressions allow measurement error along the independent variable to be considered and an uncertainty weight along each axis for each point to be included.

\section{Results and discussions}

\subsection{Comparison of surface level aerosol scattering data and extinction coefficient derived from lidar mea- surements}

We compared the scattering coefficient for near-surface aerosol, measured with the nephelometer, with the corresponding extinction coefficient $\left(c_{\text {ext,527 }}\right)$ obtained at the low- est altitude bin $(400 \mathrm{~m})$ from the lidar inversion (Welton, 1998, Voss et al., 2001a). The biases and uncertainties of the lidar inversion process are discussed in Welton et al. (2000), but an important point is that the lidar inversion uses a column average lidar ratio (constrained by the column AOD) which can lead to under- or overestimation of the aerosol extinction at a given altitude. In addition, direct comparison is complicated by the fact that these measurements were made at different relative humidities and temperatures and correspond to slightly different altitudes. In particular, the lidar measured scattering by hydrated aerosols at ambient relative humidity whereas the nephelometer measured scattering by dry aerosols; thus, differences can be expected (Zieger et al., 2011). The impact of hygroscopic growth on the aerosol light scattering coefficient is usually described by the scattering enhancement factor, $f(\mathrm{RH})$, at a given wavelength, $\lambda$, which is defined as

$f(\mathrm{RH})=b(\mathrm{RH}) / b\left(\mathrm{RH}_{\mathrm{dry}}\right)$.

The internal $\mathrm{RH}$ within the nephelometer was constrained to be $<40 \%$, and thus is considered dry aerosol (WMO/GAW, 2003). Modeled and measured scattering enhancement factors, $f(\mathrm{RH})$, have been described for different types of aerosols including maritime (Carrico et al., 1998, 2003; Wang et al., 2007), urban (Yan et al., 2008), continental (Sheridan et al., 2001), biomass burning (Kotchenruther and Hobbs, 1998), and free tropospheric (Fierz-Schmidhauser et al., 2010). At an ambient RH of $80 \%, f(\mathrm{RH})$ for sea salt has been reported to range from 1.8 to 3.2 (Lewis and Schwartz, 2004)

Another factor which describes the hygroscopic growth is the $\gamma$ (Quinn et al., 2005) defined by

$\gamma=\frac{\ln (f(\mathrm{RH}))}{\ln \left(\frac{100-\mathrm{RH}_{\mathrm{dry}}}{100-\mathrm{RH}_{\mathrm{dr}}}\right)}$.

This factor is useful as it allows $f(\mathrm{RH})$ determined at variable values of ambient $\mathrm{RH}$ to be compared. Values of $\gamma$ have been found to vary between 0.1 and 1 (Quinn et al., 2005; Massoli et al., 2009; Clarke et al., 2007; Gasso et al., 2000).

The retrieved lidar extinction coefficient at the lowest height bin and the $b_{\text {bulk-surf measured by the nephelometer }}$ were found to be correlated $\left(r^{2}=0.56\right)$ but the slope differs significantly from 1 (Fig. 1). When the data set is broken into the flow regime categories described earlier, the Ocean category $\left(r^{2}=0.41\right)$ exhibited the lowest correlation between the surface scattering and the lidar extinction, whereas the Africa category $\left(r^{2}=0.84\right)$ exhibited the highest correlation coefficient. Interestingly the Africa regime stood out in terms of the $\mathrm{RH}$ at $400 \mathrm{~m}$, with a consistently higher $\mathrm{RH}$ (mean of $80 \%$ ) relative to the other flow regimes for which $\mathrm{RHs}$ typically ranged from $60 \%$ to $76 \%$ but were more variable. The higher RH is most likely because this flow regime was over the tropical North Atlantic Ocean for several days during transport to Bermuda. 
Table 1. Averages resulting from the comparison of MPL extinction and surface nephelometer extinction broken into flow regimes, with standard deviation $(\sigma)$.

\begin{tabular}{lccccc}
\hline Flow Regime & Number of points & $\mathrm{RH}(\%)$ & $f(\mathrm{RH})$ & $\gamma$ & $r^{2}$ \\
\hline NEUS & 21 & $62 \pm 5$ & $4.2 \pm 1.6$ & $2.3 \pm 0.8$ & 0.52 \\
East-SEUS & 53 & $70 \pm 11$ & $4.3 \pm 1.7$ & $1.8 \pm 1.0$ & 0.61 \\
Africa & 8 & $80 \pm 2$ & $7.4 \pm 2.6$ & $1.6 \pm 0.2$ & 0.84 \\
Ocean & 18 & $76 \pm 11$ & $5.3 \pm 2.2$ & $1.7 \pm 1.3$ & 0.41 \\
North & 14 & $61 \pm 7$ & $3.7 \pm 1.3$ & $1.6 \pm 0.2$ & 0.65 \\
TOTAL & 114 & $69 \pm 11$ & $4.6 \pm 2.0$ & $1.9 \pm 0.9$ & 0.56 \\
\hline
\end{tabular}

The extinction coefficient retrieved at the lowest altitude bin $(400 \mathrm{~m})$ was on average $4.6( \pm 2.0)$ times greater than the scattering coefficient measured with the nephelometer. Along with differences in magnitude of aerosol at the surface or at $400 \mathrm{~m}$, two other factors may influence this ratio; the $f(\mathrm{RH})$ factor and neglecting absorption, which contributes to extinction but not scattering. Assuming that absorption is negligible, $f(\mathrm{RH})$ can be inferred from the lidar extinction divided by the surface scattering, which for the total data set corresponds to $4.6( \pm 2.0)$ (the value noted above). When broken into flow regimes, $f(\mathrm{RH})$ for the Africa flow regime of $7.4( \pm 2.6)$ is significantly greater that those for the other regimes. This difference is driven in part by the higher average RH associated with this regime (e.g., Zieger et al., 2011). We note that absorption by Saharan dust contributes significantly to extinction under African flow (e.g., Moody et al., 2014) and, thus, probably also contributed to the apparently higher $f(\mathrm{RH})$ inferred by this approach. However, the strongest absorption by dust is in the UV and blue region whereas the measurement wavelength of the nephelometer is $530 \mathrm{~nm}$ (Kaufman et al., 2001) and the lidar wavelength is $527 \mathrm{~nm}$.

We investigated the dependence of the $f(\mathrm{RH})$ as calculated above, on RH, both with the total data set and as a function of flow regime but found no clear dependence. The lack of dependence probably reflects variability introduced by other factors including aerosol composition and hysteresis introduced by differences between deliquescence and efflorescence RHs (Zieger et al., 2013).

We also calculated $\gamma$ for the data set, broken down by flow regime, which is shown in Table 1. In calculating $\gamma$ we excluded two data points for which the ambient RH was very close to the $\mathrm{RH}_{\mathrm{dry}}$ in the nephelometer, which causes Eq. (5) to become singular. Because the ambient RH was consistently elevated for the Africa flow, $\gamma$ for this flow fell into the range of the other flow regimes. All of these values are significantly higher than the values for $\gamma$ reported in the literature (Quinn et al., 2005; Massoli et al., 2009; Clarke et al., 2007; Gasso et al., 2000) as are the values of $f(\mathrm{RH})$ where values of 1.0-3.2 are more common (Li-Jones et al., 1998; Carrico et al., 2003; Lewis and Schwartz, 2004). Calculating $f(\mathrm{RH})$ with Eq. (4), or $\gamma$ with Eq. (5), using the lidar value

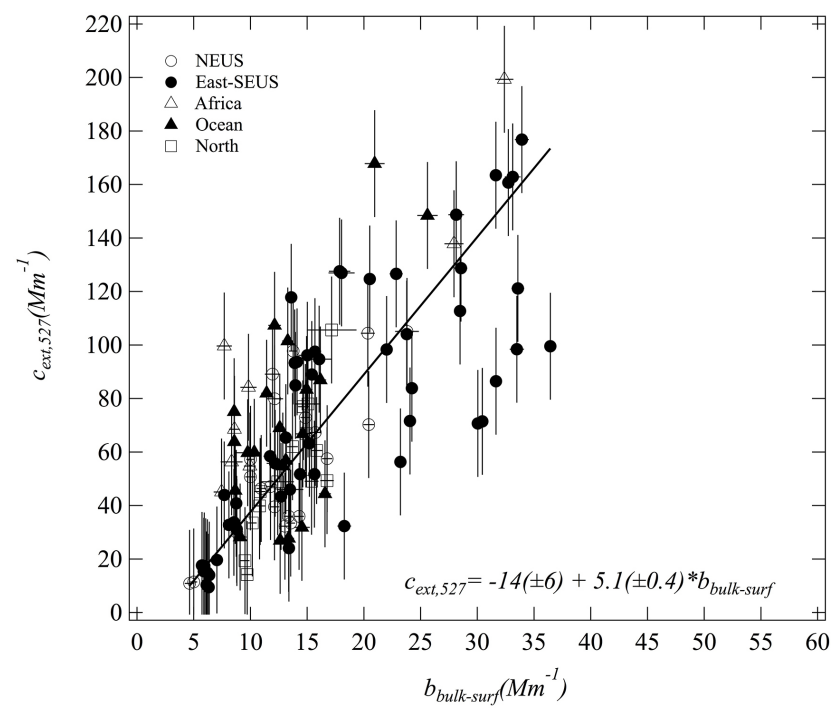

Figure 1. Scatterplot of the hourly averaged daytime extinction coefficient at the lowest height bin retrieved from the MPL data $\left(c_{\text {ext }, 527}\right)$ vs. the scattering coefficient $\left(b_{\text {bulk-surf }}\right)$. Values in parentheses in the equation are standard errors and $r^{2}=0.56$. Error bars depict standard deviation for the hourly averaged scattering coefficient; for extinction, the approximate uncertainty in the inversion result is shown. The regression is as described in Sect. 2.3.6.

at $400 \mathrm{~m}$ and the surface nephelometer value implicitly ignores any effect due to column variations between these two heights in aerosol abundance. As we show in Sect. 3.5 below, there is significant vertical variation of extinction, as derived by lidar, even in the lower $1 \mathrm{~km}$, thus these $f(\mathrm{RH})$ and $\gamma$ values include many factors beyond just the RH value. Without other in situ measurements in the column, it is not possible to separate the effect of $f(\mathrm{RH})$ or $\gamma$ from differences in aerosol abundance or other changes in the aerosol type.

\subsection{Column AOD and scattering coefficient for bulk aerosol in sectored near-surface air}

Extinction is typically dominated by scattering (Kokanovsky, 2008). Consequently, if the optical properties and quantities of aerosols near the surface are representative of those in the overlying column, $\tau$ and the scattering coefficient for 
Table 2. Monthly average values of $\tau_{500}, b_{\text {bulk-surf }}, \alpha$, and $R_{\text {sub-surf }}$ with standard deviation $(\sigma)$. Number of hourly average data (N) used to get monthly average aerosol data are reported in parentheses in the second column.

\begin{tabular}{lcccc}
\hline Months & $\tau_{500} \pm \sigma(N)$ & $b_{\text {bulk-surf }} \pm \sigma \mathrm{Mm}^{-1}$ & $\alpha \pm \sigma$ & $R_{\text {sub-surf }} \pm \sigma$ \\
\hline January & $0.09 \pm 0.02(9)$ & $16.21 \pm 4.01$ & $0.77 \pm 0.37$ & $0.61 \pm 0.19$ \\
February & $0.09 \pm 0.01(6)$ & $6.96 \pm 3.43$ & $0.76 \pm 0.16$ & $0.53 \pm 0.04$ \\
March & $0.10 \pm 0.01(50)$ & $9.35 \pm 3.94$ & $0.94 \pm 0.21$ & $0.50 \pm 0.13$ \\
April & $0.14 \pm 0.03(56)$ & $17.23 \pm 6.55$ & $1.09 \pm 0.29$ & $0.70 \pm 0.10$ \\
May & $0.13 \pm 0.03(15)$ & $14.82 \pm 4.41$ & $0.59 \pm 0.15$ & $0.45 \pm 0.07$ \\
June & $0.15 \pm 0.06(6)$ & $12.84 \pm 3.47$ & $1.27 \pm 0.11$ & $0.67 \pm 0.04$ \\
\hline
\end{tabular}

bulk aerosol ( $\left.b_{\text {bulk-surf }}\right)$ near the surface could be correlated. To obtain coincident data sets and reduce associated problems due to temporal variability of meteorological conditions (such as wind speed, relative humidity) and air mass transport (Calvello et al., 2010), we report column aerosol data that correspond to the periods of near-surface measurements. The paired hourly averaged data (AOD at $500 \mathrm{~nm}, \tau_{500}$, and $b_{\text {bulk-surf }}$ ) correspond to those having a minimum of three AOD measurements and thus are restricted to clear-sky situations. As before, we have neglected the impact of absorption in the comparison of an extinction (AOD) with the scattering measurement ( $\left.b_{\text {bulk-surf }}\right)$, but at this site the single scattering albedo at the surface was generally much higher than 0.9 , so this is a small $(<10 \%)$ effect but may contribute slightly to the variability of the relationship between AOD and $b_{\text {bulk-surf }}$.

Time series $\tau_{500}$ and $b_{\text {bulk-surf }}$ are generally correlated and $r^{2}=0.49$ (Fig. 2a and b); deviations reflect the influence of the variability in the vertical structure of the distribution of aerosol mass, size distributions, morphology, and composition within the column (Bergin et al., 2000; Voss et al., 2001a). Because $\tau_{500}$ is integrated over the whole column, there is much more scatter due to the additional influence of the vertical structure variations than was the case for $c_{\text {ext,527 }}$ at $400 \mathrm{~m}$ and $b_{\text {bulk-surf. Interestingly, there is not a strong }}$ variation in the correlation between these two parameters with flow regime, as opposed to the case of lidar extinction. The North regime had the highest correlation $\left(r^{2}=0.65\right)$ and NEUS had the lowest $\left(r^{2}=0.45\right)$. Correlations between $\tau_{500}$ and $b_{\text {bulk-surf }}$ at Bermuda fell within the range of those reported over land $\left(r^{2}=0.55-0.57\right.$; Bergin et al., 2000; Andrews et al., 2004; Slater and Dibb, 2004).

Over the 6-month period of this study, measured surface $b_{\text {bulk-surf }}$ and $\tau_{500}$ did not vary systematically by flow regime. The fit of $\tau_{500}$ to $b_{\text {bulk-surf was used to generate an error fac- }}$ tor, which indicated the degree of correlation between the surface value and the column measurement. As noted previously, we calculated the lapse rate for the lower atmosphere (less than $1 \mathrm{~km}$ ) using the available radiosonde data. Only two radiosonde measurements were available each day and the one nearest in time to the optical measurement was used in the analysis. However this meant it was possible to have a
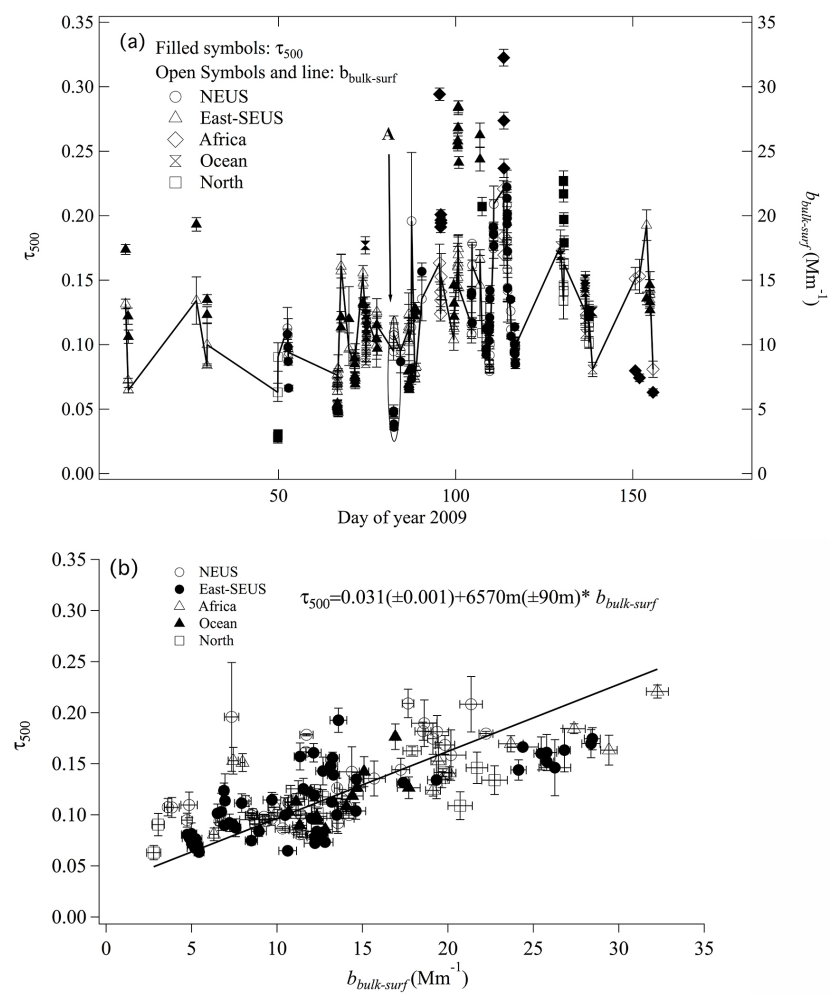

Figure 2. (a) Time series column $\tau_{500}$ derived from Cimel Sunphotometer (AERONET products) and (b) the corresponding $b_{\text {bulk-surf }}$ scatterplot of these two parameters. The line in (b) is as described in 2.3.6; $r^{2}=0.49$. Error bars depict standard deviation.

time difference between the measurement and the radiosonde profile of up to $6 \mathrm{~h}$.

Vertical profiles of aerosol extinction from MPLNET on 23 March 2009 at 13:42 and 13:57 UTC (DOY 82 (day of year); marked by A in Fig. 2a) illustrate an example of a large divergence between $\tau_{500}$ and $b_{\text {bulk-surf }}$ (Fig. 3). These profiles correspond to average $\tau_{500}$ but remarkably low $b_{\text {bulk-surf }}$ relative to the corresponding values for the entire study period. It is evident that the enhanced extinction associated with an elevated aerosol layer at approximately $1.8 \mathrm{~km}$ is responsible for a high $\tau_{500}$ relative to $b_{\text {bulk-surf }}$. This example was under 


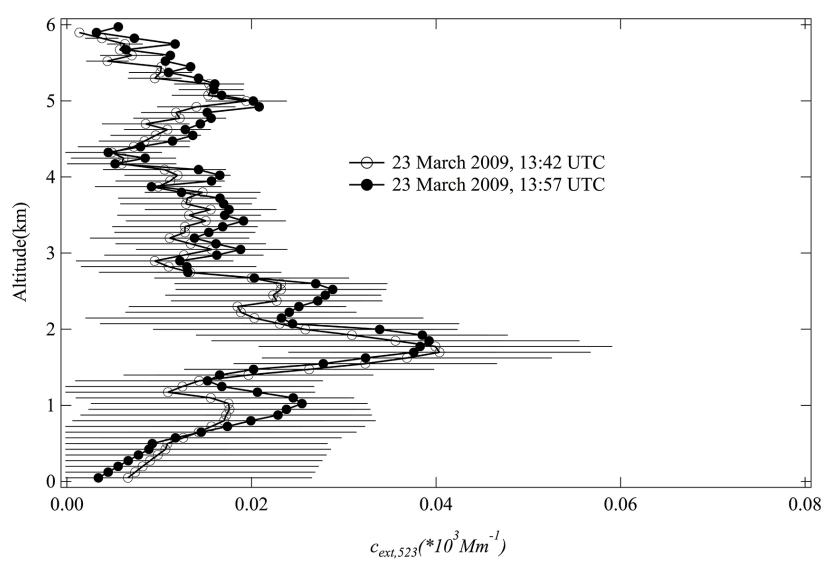

Figure 3. Twenty-minute average MPL aerosol extinction profiles at $527 \mathrm{~nm}$ for two time periods on DOY 82. The error bars depict uncertainty of retrieval. $\tau_{500}$ during this period was 0.11 . The flow regime on this day was NEUS.

NEUS flow, which did have the lowest correlation on average $\left(r^{2}=0.45\right)$.

Monthly averages for the paired data subsets are reported in Table 2. For the entire analysis period, the mean $\tau_{500}$ was $0.12 \pm 0.03$ and the range was $0.06 \pm 0.01$ to $0.22 \pm 0.01$. The average value of $\tau_{500}$ was statistically indistinguishable from the global-averaged oceanic AOD $(\sim 0.11)$ reported by Smirnov et al. (2009). The mean near-surface scattering co-

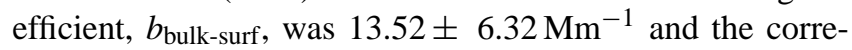
sponding range was $2.78 \pm 0.41$ to $32.25 \pm 0.64 \mathrm{Mm}^{-1}$. Minimum and maximum values for $\tau_{500}$ and $b_{\text {bulk-surf were ob- }}$ served at the same time and day.

\subsection{Sub- $\mu \mathrm{m}$ scattering fraction for sectored near-surface data and column-averaged extinction Ångström exponent $(\alpha)$}

The sub- $\mu$ m scattering fraction $\left(R_{\text {sub-surf }}\right)$ for the aerosol population is the ratio of the scattering coefficient for the sub$\mu \mathrm{m}$-diameter size fraction to the scattering coefficient for bulk aerosol (i.e., $b_{\text {sub-surf }}$ / $b_{\text {bulk-surf }}$ ), which provides an indication of the relative contribution of small particles to total scattering and is an intensive parameter, i.e., depends on the physical characteristics of the aerosol rather than simply quantity.

The extinction Ångström exponent $(\alpha)$ was calculated from the spectral AOD using the following formula:

$\alpha=-\frac{\log \left(\frac{\tau_{1}}{\tau_{2}}\right)}{\log \left(\frac{\lambda_{1}}{\lambda_{2}}\right)}$,

where $\tau_{1}$ and $\tau_{2}$ are the column AOD at the corresponding wavelengths $\lambda_{1}$ and $\lambda_{2}$. When $\alpha$ is computed over a sufficiently large wavelength interval, including both the visible $(440 \mathrm{~nm})$ and near infrared $(870 \mathrm{~nm})$, it is sensitive to the rel-

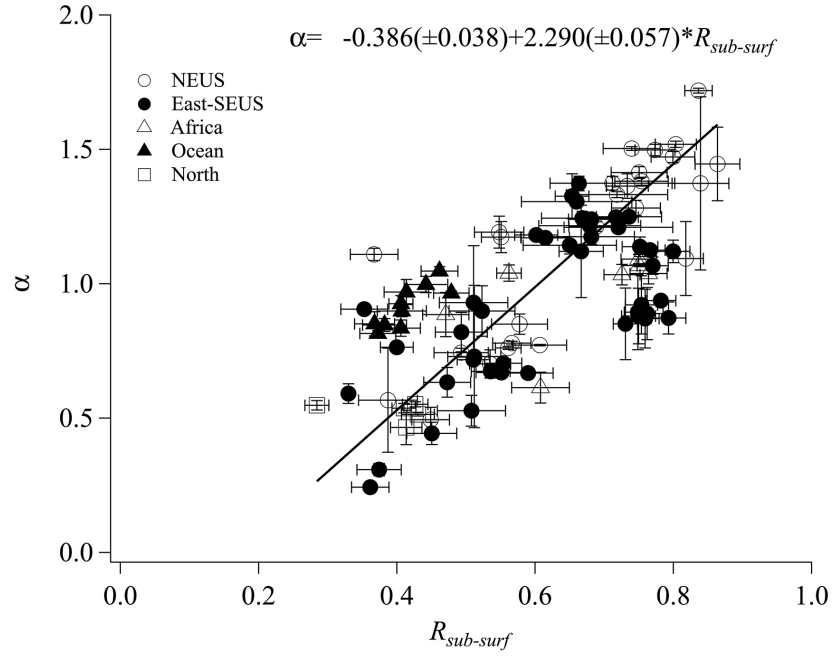

Figure 4. Hourly averaged column $\alpha$ versus hourly averaged $R_{\text {sub-surf for near-surface aerosol. The line depicts a regression as }}$ described in Sect. 2.3.6, and $r^{2}=0.49$. Vertical and horizontal error bars depict standard deviations of the hourly averaged data.

ative contributions of fine and coarse mode particles; $\alpha$ increases with an increasing contribution of fine-mode versus coarse-mode aerosol (Schuster et al., 2006). A scatterplot of the hourly average $\alpha$ calculated from the instantaneous spectral AODs from AERONET at $400 \mathrm{~nm}$ and $870 \mathrm{~nm}$ versus $R_{\text {sub-surf }}$ based on the hourly averaged near-surface sectored air is shown in Fig. 4. The correlation coefficient $\left(r^{2}=0.49\right)$ between $\alpha$ and $R_{\text {sub-surf }}$ indicates that the relative variability in the extinction associated with the column-averaged size distribution is similar to that associated with aerosols near the surface. Relative to sub- $\mu \mathrm{m}$ aerosol size fractions, super$\mu \mathrm{m}$-size fractions are associated with greater dry-deposition velocities and consequently, on average, their concentrations decrease more rapidly with altitude (e.g., Lewis and Schwartz, 2006). Variability in vertical gradients of the size distribution as a function of wind velocity and other factors contributes to variability around the regression line of Fig. 4. Variability among correlation coefficients for data subsets partitioned by flow regime reflects the small number of pairs of measurements for the Africa and North flow regimes and the small variation of these parameters for the existing paired measurements.

The Ångström exponent, being an intensive parameter, varies as a function of flow regime (Table 3) and thus source region. When $\alpha$ is less than 1 , extinction is dominated by super- $\mu$ m-diameter particles, and when greater than 1, extinction is dominated by sub- $\mu$ m-diameter particles (Eck et al., 1999; Reid et al., 1998). Low Ångström exponents were a characteristic of the North flow (median was $0.57 \pm 0.18$ ). Angström exponents for the other flow regimes ranged from 0.9 to 1.0 and were statistically indistinguishable. For $R_{\text {sub-surf }}$, three flow regimes (NEUS, East-SEUS, 
Table 3. Average Ångström exponent, $\alpha$, and $R_{\text {sub-surf }}$, along with the correlation between these factors broken down by flow regime, with standard deviation $(\sigma)$.

\begin{tabular}{lccc}
\hline Flow regime & $\alpha$ & $R_{\text {sub-surf }}$ & $r^{2}$ \\
\hline NEUS & $1.05 \pm 0.32$ & $0.66 \pm 0.14$ & 0.66 \\
East-SEUS & $0.88 \pm 0.31$ & $0.62 \pm 0.13$ & 0.43 \\
Africa & $0.91 \pm 0.24$ & $0.66 \pm 0.11$ & 0.25 \\
Ocean & $0.88 \pm 0.18$ & $0.41 \pm 0.04$ & 0.70 \\
North & $0.57 \pm 0.18$ & $0.39 \pm 0.06$ & 0.12 \\
\hline
\end{tabular}

and Africa) exhibited values ranging from 0.62 to 0.63 with standard deviations of 0.11 to 0.13 . The other two flow regimes (Ocean and North) exhibited lower mean values (0.39 and 0.41 , respectively) and standard deviations (0.04 and 0.06 , respectively). $R_{\text {sub-surf }}$ corresponds to measurements with the nephelometer at less than $40 \% \mathrm{RH}$, where $\alpha$ was calculated from the column measurements at ambient RH. The low standard deviations for $R_{\text {sub-surf }}$ associated with the Ocean and North regimes indicate that size distributions were relatively consistent, at least after drying, whereas the greater standard deviations for the other regimes indicate greater variability in size distributions for aerosol populations that were more heavily influenced by continental sources. Interestingly, NEUS, East-SEUS, and Africa were the three regimes for which $c_{\text {ext,527 }}$ and $b_{\text {bulk-surf }}$ were better correlated. The lower value of $R_{\text {sub-surf }}$ would signify that even after drying, the Ocean and North regime were more strongly influenced by large particles at the surface. The difference between Ångström exponents indicate that this influence of large particles decreases with altitude for the Ocean case, while the large particles maintain a larger influence over the whole column for the North case.

An analysis of the residuals between the measured Ångström exponent and the predicted Ångström exponent, based on $R_{\text {sub-surf }}$, and the lapse rate did not show a relationship indicating that these residuals did not increase under more stable atmospheric conditions. In general though, there was a correlation of the residuals between the measured AOD and the AOD predicted with $b_{\text {bulk-surf }}$ and the residuals of the measured extinction Ångström exponent and the extinction Ångström exponent predicted with $R_{\text {sub-surf }}$. In other words, if the column measurement was not well predicted with the surface measurement for one parameter, it was also not well correlated for the other.

\subsection{Sub- $\mu \mathrm{m}$ scattering fraction of light in sectored near-surface air and the column average}

We also compared the sub- $\mu \mathrm{m}$ scattering fraction $\left(R_{\text {sub-col }}\right)$ determined with Mie calculations using the column-averaged parameters (size distribution and index of refraction), with the near-surface sub- $\mu \mathrm{m}$ scattering fraction $\left(R_{\text {sub-surf }}\right)$ based on hourly averages (Fig. 5). Since the AERONET inver-

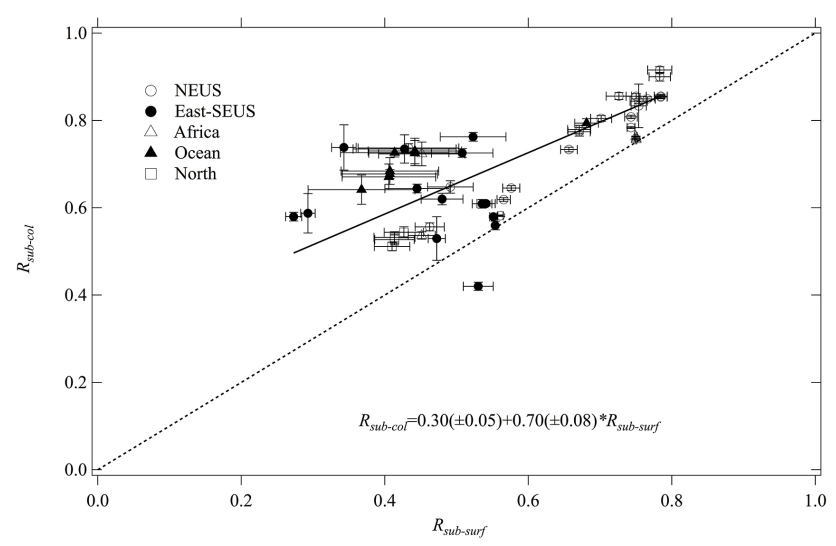

Figure 5. Scatterplot of column and near-surface sub- $\mu$ m scattering fraction of light. The solid line depicts regression as described in Sect. 2.3.6, values in parentheses correspond to standard errors, and $r^{2}=0.50$. The dashed line is the $1: 1$ line.

sions to obtain the size distribution and index of refraction require clear sky in many directions, there were relatively few points available for this comparison. For the North, Africa, and Ocean flow regimes, there was only a single day for each flow. The $r^{2}$ for the total data set (52 points) was 0.50 . The $r^{2}$ for the NEUS was 0.60 whereas that for the East-SEUS was 0.02. However, in general the surface values were less than the corresponding column values and relative differences were greater at lower surface $R_{\text {sub-surf. These relationships indicate that scattering by the }}$ super- $\mu \mathrm{m}$-size fraction was greater near the surface relative to the column, which is consistent with expectations based on the relatively greater concentrations of super- $\mu \mathrm{m}$-diameter marine aerosol in near-surface air. We also found a modest dependence in relative variability as a function of wind speed, as measured at the site. We chose a value of wind speed to characterize low winds, where no whitecaps and wave breaking would be expected (less than $4 \mathrm{~m} \mathrm{~s}^{-1}$ ), and a value at which whitecaps and wave breaking will be evident (greater than $7 \mathrm{~m} \mathrm{~s}^{-1}$ ) (Callaghan et al., 2008). At low wind speeds (less than $4 \mathrm{~m} \mathrm{~s}^{-1}$ ), $R_{\text {sub-col }}$ and $R_{\text {sub-surf }}$ average $0.74( \pm 0.13)$ and $0.64( \pm 0.13)$, respectively, whereas at higher wind speeds (greater than $7 \mathrm{~m} \mathrm{~s}^{-1}$ ), $R_{\text {sub-col }}$ and

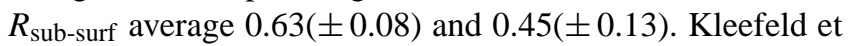
al. (2002) report similar relationships. These results reflect the greater production fluxes and higher concentrations of super- $\mu \mathrm{m}$ marine aerosols at higher wind speeds, along with stronger vertical gradients in aerosol mass and associated influences on light scattering by super- $\mu \mathrm{m}$ aerosol size fractions.

In general the increased influence of large particles at the surface relative to the column is opposite to that found in studies over land (Sheridan et al., 2012) and previously found over the ocean in some cases (Quinn et al., 2004). Sheridan et al. (2012) postulated that their lower altitude measurements 


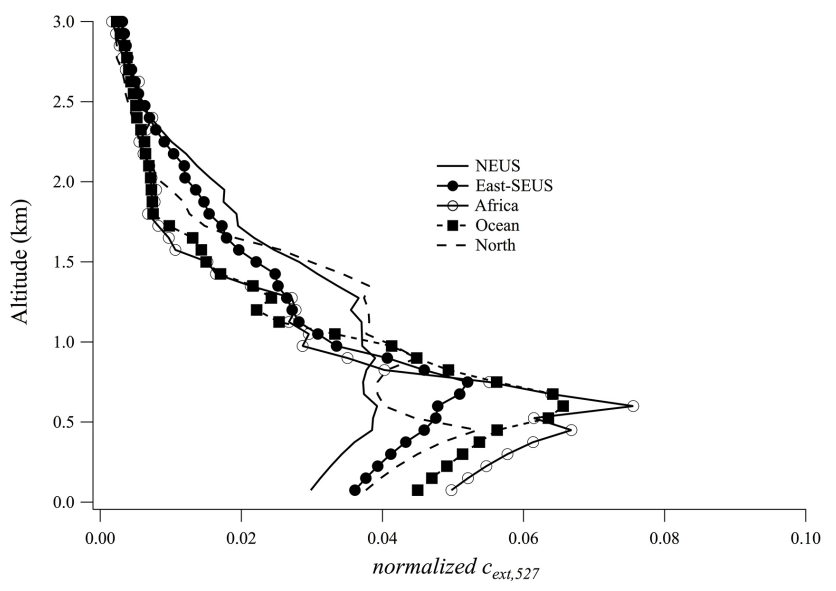

Figure 6. Normalized lidar profiles, averaged over flow regimes. The standard deviation is not shown in this figure, but was approximately 0.02 for altitudes less than $2 \mathrm{~km}$.

might have been affected by local sources of small dust particles. In Quinn et al. (2004) the differences were more significant in the case of dust and pollution aerosols at optical depths much larger than observed in this data set.

\subsection{Average lidar profiles}

To investigate the effect of flow regime on the vertical profile of the aerosols, as determined with the lidar inversions, we classified the available lidar profiles by flow regime. Each profile was then normalized by its integral (effectively the lidar-derived optical depth), and these normalized profiles were averaged for each flow regime. The resultant averages are shown in Fig. 6. The standard deviations for the average are not shown, but are quite large (approximately 0.02), reflecting the variability of the profiles within each flow classification. What can be seen in this figure is that the North and NEUS flow have a larger portion of the extinction at higher altitudes. We calculated the altitude where half of the AOD is due to aerosols above this altitude and half below to get a quantitative measure of the weighting of the profiles. For the Africa and Ocean profiles, this altitude was approximately $600 \mathrm{~m}$. For the North and East-SEUS flow this value was approximately $900 \mathrm{~m}$, while it was slightly higher $(1 \mathrm{~km})$ for NEUS.

\section{Conclusions}

Optical properties of aerosols in near-surface air and in the overlying column were measured in parallel with a nephelometer, Cimel Sunphotometer, and a micro-pulse lidar at Bermuda from January 2009 to June 2009.

For extensive parameters, the $c_{\text {ext, } 527}$ at $400 \mathrm{~m}$ was correlated with scattering measured at the surface with the nephelometer, $b_{\text {bulk-surf }}\left(r^{2}=0.56\right.$ based on all data). The de- gree of correlation varied as a function of flow regime with the highest correlation coefficient associated with the Africa flow. The correlation coefficient for AOD versus surface scatter was within the same range $\left(r^{2}=0.50\right.$ for all data) but exhibited little variability among flow regimes $\left(r^{2}=0.45\right.$ to 0.65 ). The AOD, because it is a column-averaged parameter, will have inherently less noise than the lidar-retrieved $c_{\text {ext,527 }}$ at a single altitude and can be measured more accurately, and thus would have a better correlation with surface scatter. We also found that there was no clear dependence of the atmospheric lapse rate, based on a nearby radiosonde station, on flow regime.

For intensive parameters, the linear regression of $\alpha$ versus $R_{\text {sub-surf }}$ exhibited an $r^{2}$ of 0.49 . For most flow regimes, $\alpha$ ranged from 0.9 to 1.0 , but, for the North flow, $\alpha$ was significantly lower $(0.57 \pm 0.18)$. The $R_{\text {sub-surf }}$ was significantly different for NEUS, East-SEUS, and Africa $(0.66 \pm 0.11)$ than for Ocean and North $(0.40 \pm 0.05)$. For the North flow, combining $\alpha$ and $R_{\text {sub-surf }}$ indicates a strong influence on scattering by the larger particles throughout the atmospheric column. For the Ocean, where $R_{\text {sub-surf }}$ is low but $\alpha$ is high, this indicates that the larger particles were a greater influence near the surface then at altitude, thus indicating a changing size distribution. When comparing $R_{\text {sub-surf }}$ and $R_{\text {sub-col }}$, the correlation was similar: $r^{2}=0.50$. However in our data set, $R_{\text {sub-surf }}$ was generally less than $R_{\text {sub-col }}$, indicating more large-particle contribution near the surface, contrary to other reports over land (Sheridan et al., 2012) and with dust/pollution aerosols over the water (Quinn et al., 2004).

Overall, the degree of correlation between the surface optical properties and column properties varies among parameters. Partitioning the data set by flow regime yielded improved correlations for some parameters such as $c_{\text {ext,527 }}$ and $b_{\text {bulk-surf. }}$ However, in general, correlation coefficients for regressions were still rather low. The main lesson from this is that, when trying to investigate the radiative effects of specific aerosols and separating the effect due to different chemical species, it is best to compare optical measurements made at the surface (such as with a nephelometer and absorption technique) with chemical measurements of the surface aerosol. Variability in vertical structure complicates direct extrapolation of near-surface optical measurements to column-averaged optical properties. Lidar can help resolve major drivers of divergence between the surface and the column; however, vertical changes in optically important properties such as the aerosol size distributions constrain the reliability of standard algorithms.

Acknowledgements. We thank Miguel Izaguirre, Kim Zeeh, and Chris Marsay for assisting in field operations and data generation and processing. Peter Sedwick and Andrew Peters supervised operations at the observatory, and the Bermuda Institute for Ocean Sciences provided outstanding logistical support. Funding was provided by the National Science Foundation through awards to 
the University of Miami (ATM 0541566) and the University of Virginia (ATM 0541570). Additional support was provided by NASA through the AERONET and MPLNET programs. MPLNET is supported by the NASA Radiation Sciences Program and NASA Earth Observing System.

Edited by: P. Quinn

\section{References}

Anderson, J. R., Buseck, P. R., and Patterson, T. L..: Characterization of the Bermuda Troposphere Aerosol by combined individual particle and bulk aerosol analysis, Atmos. Environ., 30, 319-338, 1996.

Anderson T. L. and Ogren, J. A.: Determining aerosol radiative properties using the TSI 3563 integrating nephelometer, Aerosol Sci. Tech., 29, 57-69, 1998.

Andrews, E., Sheridan, P. J., Ogren, J. A., and Ferrare, R.: In situ aerosol profiles over the Southern Great Plains cloud and radiation test bed site: 1: Aerosol optical properties, J. Geophys. Res., 109, D06208, doi:10.1029/2003JD004025, 2004.

Bates, T. S., Anderson, T. L., Baynard, T., Bond, T., Boucher, O., Carmichael, G., Clarke, A., Erlick, C., Guo, H., Horowitz, L., Howell, S., Kulkarni, S., Maring, H., McComiskey, A., Middlebrook, A., Noone, K., O’Dowd, C. D., Ogren, J., Penner, J., Quinn, P. K., Ravishankara, A. R., Savoie, D. L., Schwartz, S. E., Shinozuka, Y., Tang, Y., Weber, R. J., and Wu, Y.: Aerosol direct radiative effects over the northwest Atlantic, northwest Pacific, and North Indian Oceans: estimates based on in-situ chemical and optical measurements and chemical transport modeling, Atmos. Chem. Phys., 6, 1657-1732, doi:10.5194/acp-6-1657-2006, 2006.

Bergin, M. H., Schwartz, S. E., Halthore, R. N., Ogren, J. A., and Hlavka, D. L.: Comparison of aerosol optical depth inferred from surface measurements with that determined by sun photometry for cloud free conditions at a continental US site, J. Geophys. Res., 105, 6807-6816, 2000.

Boggs, P. T., Byrd, R. H., Donaldson, J. R., and Schnabel, R. B.: Algorithm 676- ODRPACK: software for Weighted Orthogonal Distance Regression, ACM Trans. Math. Softw., 15, 348-364, 1989.

Bohren, G. F. and Huffman, D. R.: Absorption and scattering of Light by small particles, A Wiley-Interscience publication, John Wiley and Sons, 544 pp., 1983.

Callaghan, A., de Leeuw, G., Cohen, L., and O'Dowd, C. D.: Relationship of oceanic whitecap coverage to wind speed and wind history, Geophys. Res. Lett., 35, L23609, doi:10.1029/2008GL036165, 2008.

Calvello, M., Esposito, F., Pavese, G., and Serio, C.: Physical and optical properties of atmospheric aerosols by in- situ and radiometric measurements, Atmos. Chem. Phys., 10, 2195-2208, doi:10.5194/acp-10-2195-2010, 2010.

Calvert, J.: Glossary of atmospheric chemistry terms, Pure Appl. Chem., 62, 2167-2219, 1990.

Campbell, J. R., Hlavka, D. L., Welton, E. J. , Flynn, C. J., Turner, D. D. , Spinhirne, J. D. , Scott, V. S., and Hwang, I. H.: Full-time, eye-safe cloud and aerosol lidar observation at Atmospheric Radiation Measurement Program sites: Instruments and data processing, J. Atmos. Ocean. Technol., 19, 431-442, 2002.
Carrico, C. M., Rood, M. J. and Ogren, J. A.: Aerosol light scattering properties at Cape Grim, Tasmania, during the First Aerosol Characterization Experiment (ACE 1), J. Geophys. Res., 103, 16565-16574, 1998.

Carrico, C. M., Kus, P., Rood, M. J., Quinn, P. K., and Bates, T. S.: Mixtures of pollution, dust, sea salt, and volcanic aerosol during ACE-Asia: Radiative properties as a function of relative humidity, J. Geophys. Res., 108, 8650, doi:10.1029/2003JD003405, 2003.

Clarke, A., McNaughton, C., Kapustin, V., Shinozuka, Y., Howell, S., Dibb, J., Zhou, J., Anderson, B., Brekhovskikh, V., Turner, H., and Pinkerton, M.: Biomass burning and pollution aerosol over North America: Organic Components and their influence on spectral optical properties and humidification response, J. Geophys. Res., 112, D12S18, doi:10.1029/2006JD007777, 2007.

Dubovik, O. and King, M. D.: A flexible inversion algorithm for the retrieval of aerosol optical properties from Sun and sky radiance measurements, J. Geophys. Res., 105, 20673-20696, 2000.

Dubovik, O., Smirnov, A., Holben, B. N., King, M. D., Kaufman, Y. J. Eck, T. F., and Slutsker, I.: Accuracy assessments of aerosol optical properties retrieved from Aerosol Robotic Network (AERONET) Sun and sky radiance measurements, J. Geophys. Res., 105, 9791-9806, 2000.

Eck, T. F., Holben, B. N., Reid, J. S., Dubovik, O., Smirnov, A., O' Neill, N. T., Slutsker, I., and Kinne, S.: Wavelength dependence of the optical depth of biomass burning, urban, and desert dust aerosols, J. Geophys. Res., 104, 31333-31350, 1999.

Ensor, D. S. and Waggoner, A. P.: Angular truncation error in the integrating nephelometer, Atmos. Environ., 4, 481-487, 1970.

Fierz-Schmidhauser, R., Zieger, P., Gysel, M., Kammermann, L., DeCarlo, P. F., Baltensperger, U., and Weingartner, E.: Measured and predicted aerosol light scattering enhancement factors at the high alpine site Jungfraujoch, Atmos. Chem. Phys., 10, 23192333, doi:10.5194/acp-10-2319-2010, 2010.

Forster, P., Ramaswamy, V., Artaxo, P., Berntsen, T., Betts, R., Fahey, D. W., Haywood, J., Lean, J., Lowe, D. C., Myhre, G., Nganga, J., Prinn, R., Raga, G., Schulz, M., and Dorland, R. V.: Changes in Atmospheric Constituents and in Radiative Forcing, in: Climate Change 2007: The Physical Science Basis. Contribution of Working Group I to the Fourth Assessment Report of the Intergovernmental Panel on Climate Change, edited by: Solomon, S., Qin, D., Manning, M., Chen, Z., Marquis, M., Averyt, K. B., Tignor, M., and Miller, H. L., Cambridge University Press, Cambridge, UK and New York, NY, USA, 129-234, 2007.

Galloway, J. N., Keene, W. C., Artz, R. S., Miller, J. M., Church, T. M. and Knap, A. H.: Processes controlling the concentrations of $\mathrm{SO}_{4}^{=}, \mathrm{NO}_{3}^{-}, \mathrm{NH}_{4}^{+}, \mathrm{H}^{+}, \mathrm{HCOO}_{T}$ and $\mathrm{CH}_{3} \mathrm{COO}_{T}$ in precipitation on Bermuda, Tellus, 41B, 427-443, 1989.

Galloway, J. N., Savoie, D. L., Keene, W. C., and Prospero, J. M.: The temporal and spatial variability of scavenging ratios for nss sulfate, nitrate, methane sulfonate and sodium in the atmosphere over the North Atlantic Ocean, Atmos. Environ. 27 A, 235-250, 1993.

Gasso, S., Hegg, D. A., Covert, D. S., Collins, D., Noone, K. J., Öström, E., Schimd, B., Russell, P. B., Lifingston, J. M., Durkee, P. A., and Jonsson, H.: Influence of humidity on the aerosol scattering coefficient and it's effect on the upwelling radiance during ACE-2, Tellus, 52B, 546-567, 2000. 
Hand, J. L., Kreidenweis, S. M., Slusser, J., and Scott, G.: Comparisons of aerosol optical properties derived from sun photometry to estimates inferred from surface measurements in Big Bend National Park, Texas, Atmos. Environ., 38, 6813-6821, 2004.

Holben, B. N., Eck, T. F., Slutsker, I., Tanre, D., Buis, J. P., Setzer, A., Vermote, E., Reagan, J. A., Kaufman, Y. J., Nakajima, T., Lavenu, F., Jankowiak, I., and Smirnov, A.: AERONET-A federated instrument network and data archive for aerosol characterization, Remote Sens. Environ. 66, 1-16, 1998.

IPCC, 2007: Contribution of working group to the fourth assessment report of the International Panel on Climate Change, Denarau Island, Nadi, Fiji, 20-22 June 2007.

Kaufman, Y. J., Gobbi, G. P., and Koren, I.: Aerosol climatology using a tunable spectral variability cloud screening of AERONET data, J. Geophys. Res., 33, L07817, doi:10.1029/2005GL025478, 2006.

Kaufman, Y. J., Tanre, D., Dubovik, O., Karnieli, A., and Remer, L. A.: Absorption of sunlight by dust as inferred from satellite and ground-based remote sensing, Geophys. Res. Lett., 28, 1479-1482, 2001.

Keene, W. C. and Savoie, D. L.: The $\mathrm{pH}$ of deliquesced sea-salt aerosol in polluted marine air, Geophys. Res. Lett., 25, 21812184, 1998.

Keene, W. C. and Savoie, D. L.: Correction to "The pH of deliquesced sea-salt aerosol in polluted marine air", Geophys. Res. Lett., 26, 1315-1316, 1999.

Keene, W. C., Pszenny, A. P, Maben, J. R., and Sander, R.: Variation in marine aerosol acidity with particle size, Geophys. Res. Lett., 29, 1101, doi:10.1029/2001GL013881, 2002.

King, M. D., Byrne, D. M., Herman, B. M., and Reagen, J. A.: Aerosol Size distributions obtained by inversion of spectral optical depths measurements, J. Atmos. Sci. 35, 2153-2167.

Kleefeld, C., O’Dowd, C. D., O'Reilly, S., Jennings, S. G., Aalto, P., Becker, E., Kunz, G., and de Leeuw, G.: Relative contribution of submicron particles $\mathrm{t}$ aerosol light scattering in the marine boundary layer, J. Geophys. Res., 107, 8103, doi:10.1029/2000JD000262, 2002.

Kokhanovsky, A. A.: Aerosol Optics Light Absorption and Scattering by Particles in the Atmosphere, Praxis Publishing Chister, UK, 148 pp., 2008.

Kotchenruther, R. A. and Hobbs, P. V.: Humidification factors of aerosols from biomass burning in Brazil, J. Geophys. Res., 103, 32081-32089, 1998.

Lawrence, M. G.: The relationship between relative humidity and the dew point temperature in moist air: A simple conversion and applications, B. Am. Meteorol. Soc., 86, 225-233, 2005.

Lewis, E. R. and Schwartz, S. E.: Sea salt aerosol production: mechanisms, methods, measurements and models-a critical review, American Geophysical Union, Washington, DC, 413 pp., 2004.

Lewis, E. R. and Schwartz, S. E.: Comment on "size distribution of sea-salt emissions as a function of relative humidity", Atmos. Environ., 40, 588-590, 2006.

Li-Jones, X., Maring, H. B., and Prospero, J. M.: Effect if relative humidity on light scattering by mineral dust aerosol as measured in the marine boundary layer over the tropical Atlantic Ocean, J. Geophys. Res., 103, 31113-31121, doi:10.1029/98JD01800, 1998.
Li, X., Maring, H., Savoie, D., Voss, K., and Prospero, J. M.: Dominance of mineral dust in aerosol light-scattering in the North Atlantic trade winds, Nature, 380, 416-419, 1996.

Liu, B. Y. H., Pui, D. Y. H., Wang, X. Q., and Lewis, C. W.: Sampling of carbon fiber aerosols, Aerosol Sci. Technol., 2, 499-511, 1983.

Massoli, P., Bates, T. S., Quinn, P. K., Lack, D. A., Baynard, T., Lerner, B. M., Tucker, S. C., Brioude, J., Stohl, A., and Williams, E. J.: Aerosol optical and hygroscopic properties during TexAQS-GoMACCS 2006 and their impact on aerosol direct radiative forcing, J. Geophys. Res., 114, D00F07, doi:10.1029/2008JD011604, 2009.

Moody, J. L., Oltmans, S. J., Levy II, H., and Merrill, J. T.: A transport climatology of tropospheric ozone, Bermuda: 1988-1991, J. Geophys. Res., 100, 7179-7194, 1995.

Moody, J. L., Keene, W. C., Cooper, O. R., Voss, K. J., Aryal, R., Eckhardt, S., Holben, B., Maben, J. R., Izaguirre, M. A., and Galloway, J. N.: Flow climatology for physicochemical properties of dichotomous aerosol over the Western North Atlantic Ocean at Bermuda, Atmos. Chem. Phys., 14, 691-717, doi:10.5194/acp14-691-2014, 2014.

Quinn, P. K., Coffman, D. J., Bates, T. S., Welton, E. J., Covert, D. S., Miller, T. L., Johnson, J. E., Maria, S., Russell, L., Arimoto, R., Carrico, C. M., Rood, M. J., and Anderson, J.: Aerosol optical properties measured on board the Ronald $\mathrm{H}$ Brown during ACE-Asia as a function of aerosol chemical composition and source region, J. Geophys. Res., 109, D19S01, doi:10.1029/2003JD004010, 28 pp., 2004.

Quinn, P. K., Bates, T. S., Baynard, T., Clarke, A. D., Onasch, T. B., Wang, W., Rood, M. J., Andrews, E., Allan, J., Carrico, C. M., Coffman, D., and Worsnop, D.: Impact of particulate organic matter on the relative humidity dependence of light scattering: A simplified parameterization, Geophys. Res. Lett., 32, L22809, doi:10.10290/2005GL024322, 2005.

Reid, J. S., Hobbs, P. V., Ferek, R. J., Blake, D. R., Martins, J. V., Dunlap, M. R. and Liousse, C.: Physical, chemical, and optical properties of regional hazes dominated by smoke in Brazil, J. Geophys. Res., 103, 32059-32080, 1998.

Russell, P. B. and Heintzenberg, J.: An overview of the ACE2 clears sky column closure experiment (CLEAR COLUMN), Tellus, Ser. B, 52, 463-483, 2000.

Savoie D. L., Arimoto, R., Keene, W. C. Prospero, J. M. Duce, R. A., and Galloway, J. N.: Marine biogenic and anthropogenic contributions to non-sea-salt sulfate in the marine boundary layer over the North Atlantic Ocean, J. Geophys. Res., 107, 4356, doi:10.1029/2001JD000970, 2002.

Schuster, G. L., Dubovik, O., and Holben, B. N.: Ångström exponent and bimodal aerosol size distributions, J. Geophys. Res., 111, D07207, doi:10.1029/2005JD006328, 2006.

Seibert, P. and Frank, A.: Source-receptor matrix calculation with Lagrangian particle dispersion model in backward mode, Atmos. Chem. Phys., 4, 51-63, doi:10.5194/acp-4-51-2014, 2004.

Sheridan, P. J., Delene, D. J., and Ogren, J. A.: Four years of continuous surface aerosol measurements from the Department of Energy's Atmospheric Radiation Measurement Program Southern Great Plains Cloud and Radiation Test bed site, J. Geophys. Res., 106, 20735-20747, 2001.

Sheridan, P. J., Andrews, E., Ogren, J. A., Tackett, J. L., and Winker, D. M.: Vertical profiles of aerosol optical properties over cen- 
tral Illinois and comparison with surface and satellite measurements, Atmos. Chem. Phys., 12, 11695-11721, doi:10.5194/acp12-11695-2012, 2012.

Slater, J. F. and Dibb, J. E.: Relationships between surface and column aerosol radiative properties and air mass transport at a rural New England site, J. Geophys. Res., 109, D01303, doi:10.1029/2003JD03406, 2004.

Smirnov, A., Holben, B. N., Eck, T. F., Dubovik, O., and Slutsker, I.: Cloud screening and Quality control Algorithms for the AERONET database, Remote Sens. Environ., 73, 337-349, 2000.

Smirnov, A., Holben, B. N., Slutsker, I., Sakerin, S. M., Macke, A., Croot, P., Zibordi, G., Quinn, P. K., Sciare, J., Kinne, S., Harvey, M., Smyth, T. J., Piketh, S., Zielinski, T., Proshutinsky, Al, Goes, J. I., Nelson, N. B., Larouche, Pl, Radionov, V. F., Goloub, P., Moorth, K., Matarrese, R., Robertson, E. J., and Jourdin, F.: Maritime aerosol network as a component of aerosol robotic network, J. Geophys. Res., 114, D06204, doi:10.1029/2008JD011257, 2009.

Spinhirne, J. D., Rall, J. A. R., and Scott, V. S.: Compact eye safe lidar systems, Rev. Laser Eng., 23, 112-118, 1995.

Stohl, A., Hittenberger, M. and Wotawa, G.: Validation of the Lagrangian particle dispersion model FLEXPART against large scale tracer experiment data, Atmos. Environ., 32, 4245-4264, 1998.

Stohl, A., Forster, C., Eckhardt, S., Spichtinger, N., Huntrieser, H., Heland, J., Schlager, H., Wilhelm, S., Arnold, F., and Cooper, O.: A backward modeling study of intercontinental pollution transport using aircraft measurements, J. Geophys. Res., 108, 4370, doi:10.1029/2002JD002862, 2003.

Stohl, A., Forster, C., Frank, A., Seibert, P., and Watawa, G.: Technical note: The Lagrangian particle dispersion model FLEXPART version 6.2, Atmos. Chem. Phys., 5, 2461-2474, doi:10.5194/acp-5-2461-2005, 2005.

Tang, I. N.: Thermodynamic and optical properties of mixed-salt aerosols of atmospheric importance, J. Geophys. Res., 102, 1883-1893, 1997.

Turekian, V. C., Macko, S. A., and Keene, W. C.: Concentrations, isotopic compositions, and sources of size-resolved, particulate organic carbon and oxalate in near-surface marine air at Bermuda during spring, J. Geophys. Res., 108, 4157, doi:10.1029/2002JD002053, 2003.

Voss, K. J., Welton, E. J., Quinn, P. K., Johnson, J. Thompson, A., and Gordon, H. R.: Lidar measurements during Aerosols 99, J. Geophys. Res., 106, 20821-20832, 2001a.

Voss, K. J, Welton, E. J., Quinn, P. K., Frouin, R., Miller, M., and Reynolds, R. M.: Aerosol optical depth measurements during the Aerosols99 experiment, J. Geophys. Res., 106, 20811-20819, $2001 b$.
Wang, W., Rood, M. J., Carrico, C. M., Covert, D. S., Quinn, P. K., and Bates, T. S.: Aerosol optical properties along the northeast coast of North America during the New England Air Quality Study - Intercontinental Transport and Chemical Transformation 2004 campaign and the influence of aerosol composition, J. Geophys. Res., 112, D10S23, doi:10.1029/2006JD007579, 2007.

Welton, E. J.: Measurements of aerosol optical properties over the ocean using sun photometry and lidar, Ph.D. dissertation, Univ of Miami, Coral Gables, Fla., 1998.

Welton, E. J., Voss, K. J., Gordon, H. R., Maring, H., Smirnov A., Holben, B. N., Schmidt, B., Livingston, J. M., Russell, P. B., Durkee, P. A., Formenti, P. and Andreae, M. O.: Ground based lidar measurements of aerosols during ACE-2: lidar description, results, and comparisons with other ground based and airborne measurements, Tellus, 52B, 636-651, 2000.

Welton, E. J., Campbell, J. R., Spinhirne, J. D., and Scott, V. S.: Global monitoring of clouds and aerosols using a network of micro-pulse lidar systems, in: Lidar Remote Sensing for Industry and Environmental Monitoring, edited by: Singh, U. N., Itabe, T., and Sugimoto, N., Proc. SPIE, 4153, 151-158, 2001.

Welton, E. J., Voss, K. J., Quinn, P. K., Flatau, P., Markowicz, K., Campbell, J. R., Spinhirne, J. D., Gordon, H. R., and Johnson, J. E.: Measurements of aerosol vertical profiles and optical properties during INDOEX 1999 using micropulse lidars, J. Geophy. Res., 107, 8019, doi:10.1029/2000JD000038, 2002.

WMO/GAW Aerosol Measurement Procedures: Guidelines and Recommendations, TD No. 153, 2003.

Yan, P., Tang, J., Huang, J., Mao, J. T., Zhou, X. J., Liu, Q., Wang, Z. F., and Zhou, H. G.: The measurement of aerosol optical properties at a rural site in northern China, Atmos. Chem. Phys., 8, 2229-2242, doi:10.5194/acp-8-2229-2008, 2008.

Zieger, P., Weingartner, E., Henzing, J., Moerman, M., de Leeuw, G., Mikkilä, J., Ehn, M., Petaäjä, T., Clémer, K., Van Roozendael, M., Yilmaz, S., Frieß, U., Irie, H., Wagner, T., Shaiganfar, R., Beirle, S., Apituley, A., Wilson, K., and Baltensperger, U.: Comparison of ambient aerosol extinction coefficients obtained from in-situ, MAX-DOAS and LIDAR measurements at Cabauw, Atmos. Chem. Phys., 11, 2603-2624, doi:10.5194/acp11-2603-2011, 2011.

Zieger, P., Fierz-Schmidhauser, R., Weingartner, E., and Baltensperger, U.: Effects of relative humidity on aerosol light scattering from different European sites, Atmos. Chem. Phys., 13, 8939-8984, doi:10.5194/acp-13-8939-2013, 2013. 